\title{
Paradoxical effects of obesity on pre- vs. post-menopausal breast cancer: The epigenetic mechanisms (Review)
}

\author{
ARMINA-LYN M. FREDERICK ${ }^{1,3}$, RICCARDO RACICOT ${ }^{1,4}$ and ZHENHUA LIU ${ }^{1,2}$ \\ ${ }^{1}$ Nutrition and Cancer Prevention Laboratory, School of Public Health and Health Sciences, \\ University of Massachusetts, Amherst, MA 01003; ${ }^{2}$ UMass Cancer Center, \\ The UMass Medical School, Worcester, MA 01655, USA
}

Received June 20, 2021; Accepted August 4, 2021

DOI: $10.3892 / \mathrm{ije} .2021 .4$

\begin{abstract}
Breast cancer (BC) has surpassed lung cancer as the most commonly diagnosed cancer among women in the US, as well as globally. A number of factors evidently contribute to the risk of developing BC, including age, physical activity, overweight/obesity, alcohol consumption, etc. It is of particular importance to study the role of body fatness and its potential influence on the risk of developing $\mathrm{BC}$, as the number of individuals with obesity has increased with an alarming rate worldwide in recent decades. Epigenetics alterations are reversible, and do not alter the DNA sequence; however, they can affect gene expression via modifiable factors, including lifestyle and environmental factors. The present review article, in addition to providing overall reviews of obesity and $\mathrm{BC}$ in association with public health, concentrated on the epigenetic phenomena, with a focus on the well-studied DNA
\end{abstract}

Correspondence to: Professor Zhenhua Liu, Nutrition and Cancer Prevention Laboratory, School of Public Health and Health Sciences, University of Massachusetts, 100 Holdsworth Way, Amherst, MA 01003, USA

E-mail: zliu@nutrition.umass.edu

Present addresses: ${ }^{3}$ Program in Experimental and Molecular Medicine, Geisel School of Medicine, Dartmouth College, Hanover, NH 03755; ${ }^{4}$ The Center for Molecular Biology, Smith College, Northampton, MA 01063, USA

\begin{abstract}
Abbreviations: $\mathrm{BC}$, breast cancer; pre-BC, pre-menopausal breast cancer; post-BC, post-menopausal breast cancer; BMI, body mass index; NHANES, the National Health and Nutrition Examination Survey; IARC, International Agency for Research on Cancer; $\mathrm{CDC}$, the Centers for Diseases Control and Prevention in the US; WCRF, World Cancer Research Fund; AICR, American Institute of Cancer Research; TNBC, triple-negative breast cancer; HPLC, high performance liquid chromatography; LINE-1, long interspersed nuclear element-1; LUMA, luminometric methylation assay
\end{abstract}

Key words: breast cancer, DNA methylation, epigenetics, folate metabolism, obesity methylation, and its role in the association between obesity and $\mathrm{BC}$. The present review aimed to provide insight into the understanding of the paradoxical effects of obesity on pre-vs. post-menopausal $\mathrm{BC}$ (pre-BC vs. post-BC), and describe the mechanisms through which folate metabolism/DNA methylation may be responsible for the protective effects of obesity on pre-BC. The literature presented in the present review article indicates that the epigenetic alterations represent a mediator in the association between obesity and BC; however, the mechanisms through which obesity differentially affects pre-vs. post-BC remain unclear. Further studies using animal models and the analyses of human tissue biopsies are thus required to delineate the paradoxical effects of obesity on BC.

\section{Contents}

1. Obesity and breast cancer

2. Epigenetic alterations in breast cancer

3. Obesity and DNA methylation

4. Obesity, DNA methylation and breast cancer

5. Folate metabolism in obesity and breast cancer

6. Conclusions and future perspectives

\section{Obesity and breast cancer}

Prevalence of breast cancer $(B C)$. BC has surpassed lung cancer as the most commonly diagnosed type of cancer among women, with $\sim 2.26$ million new cases and $\sim 685,000$ deaths recorded globally in 2020 . These numbers represent $24.5 \%$ of all new cancer cases and $15.5 \%$ of cancer-attributed mortality in women, respectively (1). In the US, the new cases of BC have also markedly increased, reaching top levels among all new cancer cases among women, with $\sim 282,000$ cases estimated in 2021 (30\%); BC also represents the 2 nd leading cause of cancer-related mortality, with 43,600 deaths (15\%), coming only second following lung cancer (2).

The $\mathrm{BC}$ incidence rates have consistently increased during the decades between 1970-2000 in a number of industrialized countries, likely reflecting changes in lifestyle associated with civilization and increased detection via mammographic screening. In the 2000 s, the incidence rates had reached a 
plateau with slight decreases in some countries (3), which were largely attributed to a reduction in the use of menopausal hormone therapy and also possibly to a stabilized screening participation rate (4-6). However, in the US, the BC incidence rates have continued to increase by $\sim 0.5 \%$ annually in recent years (7). This is attributed at least in part to increased body weight (8).

Epidemic of obesity. The prevalence of obesity, which is defined as a body mass index $(\mathrm{BMI}) \geq 30$, has markedly increased in recent decades; globally, the incidence of obesity has almost tripled since the 1970s (9). Worldwide, $>1.9$ billion adults aged $\geq 18$ years were overweight, accounting for $39 \%$ of the population in 2016 . Of these, $>650$ million, $13 \%$ of the population, were obese (9). In the US, according to the National Health and Nutrition Examination Survey (NHANES) data from 1999-2000 through 2017-2018, the age-adjusted prevalence of obesity among adults aged $>20$ years increased from 30.5 to $42.4 \%$, representing a $200 \%$ increase from 1976-1980. The prevalence of severe obesity (BMI $\geq 40)$ increased from 4.7 to $9.2 \%$, and it was extremely rare before the early 1970s $(10,11)$. Although the increasing trend in the prevalence of obesity has recently exhibited a decrease, a further increase, up to $\sim 50 \%$ by the year 2030 , is still projected $(12,13)$.

Obesity is associated with a variety of health risks, and severe obesity further increases the risk of obesity-related complications (14-16). Obesity is a risk factor for type 2 diabetes (17-20), cardiovascular diseases $(21,22)$, inflammatory bowel diseases $(23,24)$ and overall mortality $(25,26)$. According to the examination of the association between obesity and US adult mortality in recent decades (1986-2006), scientists have reported that obesity accounted for $18 \%$ of deaths among African Americans and Caucasians between the ages of 40 and 85 , which is significantly greater than the $\sim 5 \%$ previously considered (27). In terms of cancer, the International Agency for Research on Cancer (IARC) has identified 13 types of cancer associated with overweight and obesity: Meningioma, multiple myeloma, adenocarcinoma of the esophagus, cancers of the thyroid, post-menopausal breast cancer (post-BC), gallbladder, stomach, liver, pancreatic, kidney, ovarian, uterine, and colorectal cancer (28). In US, the Centers for Diseases Control and Prevention (CDC) have reported that overweight and obesity constitute $40 \%$ of the cancer cases diagnosed (29). Therefore, the rising rate in obesity is currently a serious public health concern.

Paradoxical effects of obesity on pre-menopausal (pre-BC) vs. post-BC. Well-established risk factors for BC are numerous, including non-modifiable factors such as age, race, family history, etc., and modifiable factors such as diet, physical activity, body weight status, alcohol consumption, hormonal status, parity and factors leading to greater birthweight or greater linear growth, etc. (30). Of these modifiable risk factors, the body weight status is of high significance as regards its association with the incidence and prognosis of cancer (31), as well as the current obesity epidemic $(9,11)$.

The associations between overweight/obesity and $\mathrm{BC}$ have become complex. The body weight status is significantly associated with the overall risk of developing BC (32). A higher BMI, higher overall energy intake and lower physical activity levels have been shown to be associated with an increased risk of developing post-BC in prospective cohort analyses (33). It was originally speculated that the body weight status was also positively associated with the risk of developing pre-BC (33). However, in recent studies, although overweight or obese weight status have been continuously shown to be positively associated with the risk of developing post-BC, this association has been indicated to be reversed in women of childbearing age (34-36). A meta-analysis of 34 cohort studies including $>2.5$ million women and almost 24,000 post-BC subjects reported that, accompanying each 5 -unit increase $\left(5 \mathrm{~kg} / \mathrm{m}^{2}\right)$ of BMI in overall adulthood, the relative risk of post-BC increased by $12 \%$ (37). For pre-BC, a meta-analysis performed by the World Cancer Research Fund/American Institute of Cancer Research (WCRF/AICR), with 37 studies and 16,371 cases, revealed a statistically significant $7 \%$ decreased risk per each 5 -unit increase in BMI in overall adulthood (30). It is currently an accepted concept that a well-established positive association exists between obesity and post-BC, whereas a reverse association exists prior to menopause $(38,39)$ (Fig. 1).

A significant challenge for understanding the cellular and molecular mechanisms of action by body fatness is the apparent increased risk of developing post-BC; however, body fatness seems to have a protective impact on pre-BC, and a high BMI in young adulthood seems to have a protective effect on post-BC. There is no single mechanism through which obesity mediates breast tumorigenesis, and different molecular mechanisms are expected in the development of pre- and post-BC. A number of studies have been conducted in order to understand the positive association between obesity and post-BC, and several mechanisms governing this association have been proposed and defined, including adipose tissue-driving circulating hormones and an obesity-associated chronic low-grade inflammatory state $(12,40)$. However, the mechanisms responsible for the associations between obesity and pre-BC are less understood, and a recent study by the authors demonstrated a potential epigenetic mechanism: Obesity influences folate metabolism and leads to an elevation in breast tissue folate levels, preventing the development of pre-BC by altering global methylation (41). Further details on this matter are discussed below, as well as in the previous study (41).

\section{Epigenetic alterations in breast cancer}

According to the 'Roadmap Epigenomics Project' of the National Institutes of Health in the US, epigenetics refers to both heritable changes in gene activity and expression, as well as to alterations in the transcriptional potential of a cell that are not necessarily heritable (42). Unlike genetic alterations, epigenetic alterations are reversible and do not alter the DNA sequence; however, epigenetic alterations can affect how the cell reads a DNA sequence. Epigenetic alterations affect gene expression via different mechanisms. The major types of epigenetic alterations include the following: i) DNA methylation, which functions by adding a chemical group (methyl group) to the DNA and alters gene expression; ii) histone modifications, which refer to adding or removing chemical groups from histones and thereby change whether a gene is unwrapped or wrapped ('on' or 'off'); and iii) non-coding 


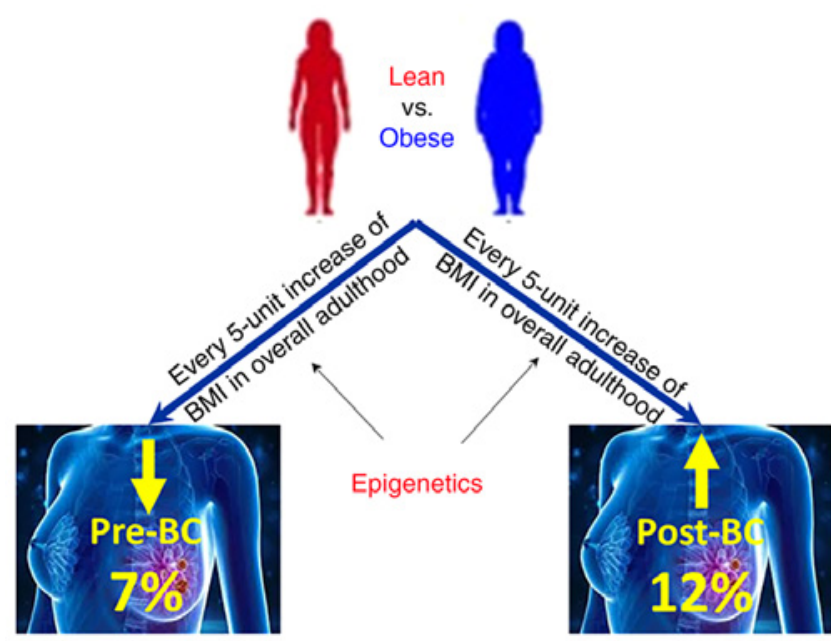

Figure 1. The apparent opposite associations between obesity and pre-BC vs. post-BC. The underlying mechanisms remain unclear. Epigenetics may play a regulatory role in these paradoxical associations, particularly as regards the protective effects on pre-BC. BC, breast cancer; pre-BC, pre-menopausal breast cancer; post-BC, post-menopausal breast cancer; BMI, body mass index.

RNA interference, which functions by attaching to coding RNA, along with certain proteins, to break down the coding RNA so that it cannot be used to yield proteins (43-46).

$\mathrm{BC}$ is a type of cancer that develops from breast tissue, mostly in women. Risk factors include both fixed factors, such as age, a prior history or a family history of BC $(47,48)$, as well as modifiable factors, such as obesity, a lack of physical exercise, alcoholism, hormone replacement therapy during menopause, and a late gestational period $(30,49)$. BC is both a genetic and epigenetic disease (50-53). While a large number of genetic mutations are causally linked to $\mathrm{BC}$, epigenetic mechanisms regulate multiple aspects of $\mathrm{BC}$ biology, from driving primary tumor growth and invasion to modulating the immune response within the tumor microenvironment. The present review article discusses the role of DNA methylation, one of the major epigenetic alterations, in the development of BC, as DNA methylation is the most extensively studied epigenetic event in cancer (54-56), and obesity elicits a myriad of changes in DNA methylation (57). BMI and menopausal status have been shown to co-vary with methylation patterns in BC (58). The present review article primarily focuses on the mechanisms through which DNA methylation mediates the contradictory associations between obesity and pre-vs. post-BC.

Global DNA methylation and BC. In cancer, two contradictory changes in DNA methylation patterns have been characterized: Global hypomethylation and gene-specific hypermethylation (59). Global hypomethylation facilitates cancer development and progression through chromosomal instability (60) and the activation of oncogenes (61) or the silencing of tumor suppressors (62). The global hypomethylation level of peripheral blood leukocyte DNA has been suggested as a potential biomarker for the risk of developing $\mathrm{BC}$ (63). In a methylome mapping at the single nucleotide resolution of a low-passage BC cell line (HCC1954) and primary human mammary epithelial cells, a widespread DNA hypomethylation was reported in BC cells, primarily at partially methylated domains in normal breast cells (62). Genes [e.g., the DNA repair gene, O-6-methylguanine-DNA methyltransferase $(M G M T)]$ within these regions were largely silenced in $\mathrm{BC}$ cells and the loss of DNA methylation in these regions was accompanied by the formation of repressive chromatin, indicating a widespread DNA hypomethylation for gene regulation through chromatin alteration (62). A recent systematic analysis found an association between global blood-derived DNA hypomethylation with a higher risk of developing BC, and the strength of the association tends to be weak for long period follow-up, indicating that global DNA methylation may be a short-term predictor of the risk of developing BC (64).

Gene-specific DNA methylation and $B C$. Compared with global hypomethylation, gene-specific hypermethylation and the silencing of tumor suppressor genes in cancer have received increasing attention over the past decades. A list of genes hypermethylated in BC has been identified and methylation signatures have been established with whole epigenome approaches $(65,66)$. A number of tumor suppressors are hypermethylated in BC cells and primary mammary tumors (43). Their biological function includes DNA repair, cell-cycle regulation, proliferation and apoptosis, cellular homeostasis, cell adhesion and invasion, etc. A list of commonly reported genes with differential methylation in $\mathrm{BC}$ is presented in Table I (66-69). A known example is the BRCAl gene, which is normally expressed in cells of the breast where, together with the $B R C A 2$ gene, are responsible for repairing damaged DNA $(70,71)$. When $B R C A 1$ is hypermethylated, it gives rise to the same pattern of gene expression as the one of BRCA1-mutated BC, a common type of hereditary BC (72). As aberrant promoter methylation patterns in tumor suppressors are common phenomena in BC, several studies have already evaluated the applicability of gene-specific hypermethylation as a predictive (73), diagnostic (74-76) or prognostic (77-79) biomarker in BC. For instance, a whole-genome methylation capture sequencing analysis of small amounts of DNA isolated from formalin-fixed, paraffin-embedded tissue from triple-negative BC (TNBC) and matched normal samples identified TNBCs into three distinct methylation clusters associated with a better or worse prognosis (79). These data highlight the prognostic potential of DNA methylation in TNBC, and provide valuable tools for the management of TNBC (79).

\section{Obesity and DNA methylation}

Substantial studies have been conducted to examine the associations between obesity and DNA methylation, focusing on the following: i) Associations, not causality, between obesity and DNA methylation; ii) the causal contribution of DNA methylation to obesity; and iii) the mediation of DNA methylation with obesity (80-82). However, the majority of studies have focused on the first two associations, and studies on the mechanisms through which obesity mediates DNA methylation are limited. As the present review concentrated on the epigenetic linkage between obesity and BC, the determination of the mechanisms through which obesity mediates DNA 
Table I. List of genes commonly differentially methylated in breast cancer.

\begin{tabular}{|c|c|c|c|}
\hline Function & Gene name & Gene ID & Biological role implicated in cancer \\
\hline DNA repair & $\begin{array}{l}\text { BRCA1 } \\
\text { BRCA2 } \\
M G M T \\
\text { MSH2 } \\
\text { MLH1 }\end{array}$ & $\begin{array}{r}672 \\
675 \\
4255 \\
4436 \\
4292\end{array}$ & $\begin{array}{l}\text { DNA repair, controlling cell growth and cell death } \\
\text { DNA repair, controlling cell growth and cell death } \\
\text { Cellular defense against mutagenesis and toxicity } \\
\text { Mismatch repair } \\
\text { Involved in DNA damage signaling }\end{array}$ \\
\hline $\begin{array}{l}\text { Cell-cycle } \\
\text { regulation }\end{array}$ & $\begin{array}{l}\text { RASSF1A } \\
\text { CCND2 } \\
\text { CDKN1A }\end{array}$ & $\begin{array}{r}11186 \\
894 \\
1026\end{array}$ & $\begin{array}{l}\text { Tumor suppressor, blocks cell cycle progression } \\
\text { Required for cell cycle G1/S transition } \\
\text { Regulates cell cycle progression at G1 }\end{array}$ \\
\hline $\begin{array}{l}\text { Proliferation } \\
\text { and apoptosis }\end{array}$ & $\begin{array}{l}C D K N 2 A \\
D A P K 1 \\
\text { SCGB3Al } \\
C D H 1\end{array}$ & $\begin{array}{r}1029 \\
1612 \\
92304 \\
999\end{array}$ & $\begin{array}{l}\text { Prevents cells from proliferating and dividing in } \\
\text { an uncontrolled manner } \\
\text { Apoptosis, autophagy } \\
\text { Cell proliferation and differentiation } \\
\text { Control proliferation, invasion, and/or metastasis }\end{array}$ \\
\hline Wnt signaling & $\begin{array}{l}\text { SFRP1 } \\
\text { SFRP2 } \\
\text { WIF1 } \\
\text { APC }\end{array}$ & $\begin{array}{r}6422 \\
6423 \\
11197 \\
324\end{array}$ & $\begin{array}{l}\text { Member of the SFRP family, WNT antagonist } \\
\text { Member of the SFRP family, WNT antagonist } \\
\text { Functions to inhibit WNT proteins } \\
\text { Tumor suppressor, prevents cells from } \\
\text { proliferating and dividing too rapidly or in an } \\
\text { uncontrolled manner } \\
\text { Creation and maintenance of epithelial cell layers }\end{array}$ \\
\hline $\begin{array}{l}\text { Hormonal } \\
\text { signaling }\end{array}$ & $\begin{array}{l}\text { ESRl } \\
P G R \\
\text { EGFR } \\
\text { GHSR }\end{array}$ & $\begin{array}{l}2099 \\
5241 \\
1956 \\
2693\end{array}$ & $\begin{array}{l}\text { Hormone binding, transcriptional activation } \\
\text { Regulate cell growth } \\
\text { Involve in cell growth } \\
\text { Regulation of energy homeostasis }\end{array}$ \\
\hline
\end{tabular}

$B R C A 1$ and 2, breast cancer type 1 and 2 susceptibility genes; $M G M T, O$-6-methylguanine-DNA methyltransferase; $M S H 2$, mutS homolog 2; $M L H 1$, mutL homolog 1; RASSF1A, Ras association domain family member 1; CCND2, cyclin D2; CDKN1A and 2A, cyclin dependent kinase inhibitor 1A and 2A; DAPK1, death associated protein kinase 1; SCGB3A1, secretoglobin family 3A member 1; CDH1, cadherin 1; SFRP1 and 2, secreted frizzled related protein 1 and 2; WIF1, WNT inhibitory factor 1; APC, APC regulator of WNT signaling pathway; CTNNB1, catenin beta 1; ESR1, estrogen receptor 1; PGR, progesterone receptor; $E G F R$, epidermal growth factor receptor; GHSR, growth hormone secretagogue receptor.

methylation is warranted. There are limited studies available providing direct insight into the cellular mechanisms through which obesity regulates DNA methylation, whereas a great number of studies have ascertained the effects of risk factors of obesity, such as high fat diet and physical activity, on DNA methylation as described below.

Obesity-related nutritional factors alter DNA methylation. Diets with an enriched fat content are associated with an elevated body weight and studies have also shown that a diet high in saturated fat is associated with aberrant DNA methylation. The study by Perfilyev et al examined studied the impact of a 7-week intake of extra amounts (+750 kcal/day) of saturated fat on the genome-wide DNA methylation in the subcutaneous adipose tissue in young healthy humans. They demonstrated that the intervention did not differ in the degree of body weight gain, but rather in the degree of DNA methylation of 125 genes [e.g., adiponectin, C1Q and collagen domain containing $(A D I P O Q)$ ] differentially methylated within adipose tissue (83). Another study demonstrated that the short-term high-fat overfeeding of healthy young men induced DNA methylation alterations in 6,508 genes in skeletal muscle biopsies. Among the top 20 most significant genes were dynamin 2 (DNM2), $M G M T$, glucose transporter type 3 (GLUT3), mannose receptor C-type $1(M R C 1)$ and acetyl-CoA acetyltransferase 2 (ACAT2) (84). In contrast to a high fat diet, caloric restriction has bene shown to reduce the impact on DNA methylation. The study performed by Milagro et al (85) demonstrated that an 8-week caloric restriction altered DNA methylation at several sites of ATPase phospholipid transporting 10A (ATP10A) and WT1 in peripheral blood mononuclear cells. Moreover, in another study, a 6-month caloric restriction resulted in a $>3 \%$ reduction of body fat and induced the hypermethylation of phospholipase $\mathrm{C}$ eta 2 (PLCH2) and PR/SET domain 8 (PRDM8) in subcutaneous adipose tissue biopsies (86).

Physical activity alters DNA methylation. Physical activity is directly associated with obesity. There is emerging evidence supporting that physical activity influences DNA methylation in humans (87). Acute high-intensity exercise has been demonstrated to elicit the hypomethylation and elevated expression 
of PPARG coactivator $1 \alpha(P G C-1 \alpha)$, pyruvate dehydrogenase kinase $4(P D K 4)$ and peroxisome proliferator-activated receptor $\delta(P P A R-\delta)$ in skeletal muscle in both humans and mice (88). A genome-wide analysis of DNA methylation in the muscle of trained mice ( 5 days/week for 4 weeks) identified $>2,700$ genes with significant methylation changes in their putative promoter regions compared with sedentary controls (89). A lifelong physical activity study demonstrated that DNA methylation was significantly lower in $>700$ promoters of genes in the skeletal muscle of physically active than inactive men, and these genes were involved in metabolism, myogenesis, contractile properties and oxidative stress resistance (90). A systematic review of 25 studies concluded that both acute and chronic exercise significantly affected DNA methylation, in a highly tissue- and gene-specific manner; among genes whose methylation levels were found to be significantly altered after exercise were those involved in metabolism [e.g., $P G C$ - $1 a$ and glutamate dehydrogenase $1(G L U D 1)]$, muscle growth [e.g., myocyte enhancer factor $2 \mathrm{~A}(M E F 2 A)]$ and inflammation [e.g. PYD and CARD domain containing (PYCARD, or ASC)] (87).

\section{Obesity, DNA methylation and breast cancer}

As described above, substantial evidence has supported the associations between obesity and DNA methylation (80-82,91,92); however, the cause and effect remains to be defined. It is also well known that alterations in DNA methylation patterns are common epigenetic aberrations in BC $(64,93)$. Dysregulated DNA methylation is directly associated with $\mathrm{BC}$ pathogenesis by controlling significant processes, including gene transcription, post-translation, the remodeling of chromatin, the imprinting of a genome, etc. (46,94-96). Some studies have examined the mediating effects of DNA methylation on the association of obesity and BC (82,97-99). However, even though it is well accepted that obesity exerts paradoxical effects on pre-vs. post-BC, studies examining the mechanisms through which obesity differentially mediates mammary DNA methylation in pre-vs. post-menopausal women are extremely limited.

Impact of obesity on gene-specific DNA methylation and BC. Although not differentiated by the menopausal status, several studies have investigated the associations between BMI and the risk of developing BC as regards gene-specific DNA methylation levels. For instance, a number of studies have demonstrated that the methylation status of $\mathrm{CpG}$ islands in the promoter regions of the $B R C A l$ gene is aberrant in patients with sporadic breast tumors when compared with healthy females or patients with benign diseases (100-106). A meta-analysis of $>40$ studies demonstrated that the frequency of $B R C A 1$ promoter methylation was significantly higher in $\mathrm{BC}$ patients than in healthy controls, and this BRCAl methylation was also associated with diminished levels of BRCA1 protein expression, metastasis, histological grade 3 and the triple-negative phenotype (71). By contrast, in a healthy cohort of dominantly obese female nurses aged 40-60 years, obesity was not associated with $B R C A 1$ or $B R C A 2$ promoter hypermethylation (107). These disparate results indirectly that indicate obesity plays a mediating role in the association between gene-specific methylation and BC. In another study, BC-specific mortality was found to be higher in obese women with promoter methylation in the $A P C$ gene [hazard ratio (HR), 2.47; 95\% confidence interval (CI), 1.43-4.27] (108). However, the data are too limited for a conclusion to be drawn regarding the mechanisms through which obesity mediates gene-specific DNA methylation in terms of the development of $\mathrm{BC}$, particularly as regards the differential impact on pre-vs. post-BC.

Impact of obesity on global DNA methylation and BC. Similar to gene-specific DNA methylation, the understanding of the mechanisms through which obesity mediates global DNA methylation are also limited. Variations in global methylation measurements $(63,109-111)$ further complicate the determination of the effects of obesity on global DNA methylation and BC. High performance liquid chromatography-based (HPLC) detection is considered the 'gold standard' of global DNA methylation (112); however, due to the considerable cost and need for specific laboratory conditions, the use of HPLC for DNA methylation profiling is less common. Two of the most popular substitutions for measuring global DNA methylation are the methylation status of long interspersed nuclear element-1 (LINE-1) and the luminometric methylation assay (LUMA). As more than one-third of methylation within the human genome is found in the CpG-rich sequences of LINEs, these transposable elements are considered a valid surrogate marker for global methylation $(113,114)$. LUMA measures DNA methylation in CCGG sequences and provides a robust estimation of the overall 5-methylcytosine $(5-\mathrm{mC})$ content in dinucleotide $\mathrm{CpG}$ sites in the whole genome $(115,116)$. Of these two methods (LUMA and LINE-1), only LINE-1 assay data are well-associated with HPLC-derived measurements, and $L I N E-1$ is often recommended over the use of LUMA alone to assess whole genome methylation patterns (117).

It has been indicated that global DNA methylation modifies the association between obesity and BC. A study on $>1,300$ patients with $\sim 15$ years of follow-up, demonstrated an increased all-cause mortality (HR, 1.81; 95\% CI, 1.19-2.74) and BC-specific mortality (HR, 2.61; 95\% CI, 1.45-4.69) among obese patients with the lowest LUMA levels (global hypomethylation) (108). Although not directly linking LINE-1 with $\mathrm{BC}$, a previous study on 156 individuals found that LINE-1 methylation was positively associated with a healthier lifestyle, yet inversely related to body fat mass in healthy young individuals (118). However, this result is inconsistent with the findings of other studies, which indicated that an elevated BMI was associated with lower LINE-1 methylation $(119,120)$ or was not associated with LINE-I (121). Another cross-sectional study on 289 healthy postmenopausal women who participated in the Alberta Physical Activity and Breast Cancer Prevention trial demonstrated that, after adjusting for important confounders, LINE-1 methylation was positively associated with $\mathrm{BMI}(\mathrm{P}=0.03)$ and multiple other adiposity parameters, including intra-abdominal fat area, body fat percentage, fat mass, waist circumference, hip circumference, current weight status, body weight at age 20 and adulthood weight gain (122).

\section{Folate metabolism in obesity and breast cancer}

To date, studies have demonstrated associations between BMI, DNA methylation (including both global and gene-specific DNA methylation) and the development of BC; however, the 


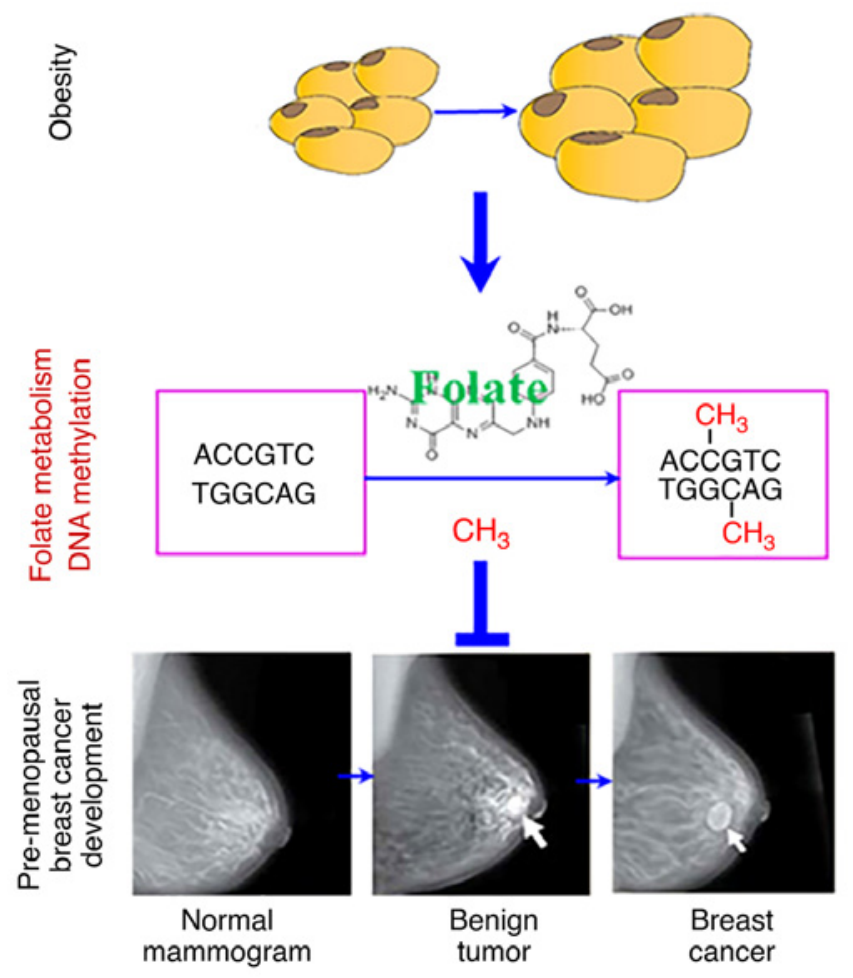

Figure 2. Folate metabolism/DNA methylation mechanism in obesity and pre-menopausal breast cancer. Obesity influences folate metabolism and leads to an elevation in breast tissue folate levels, which prevents the development of pre-menopausal breast cancer via an epigenetic mechanism (DNA methylation).

clear gene-specific methylation profile that links obesity with $\mathrm{BC}$ has yet to be defined and the results on global methylation are inconsistent. However, ample DNA methylation data are based on peripheral tissues, e.g., blood cells, which do not directly reflect the methylation status in mammary tissue (123). More importantly, the majority of studies have only described an association and 'the chicken or the egg' causality dilemma remains to be resolved.

Folate metabolism, which supports a broader set of transformations known as one-carbon metabolism, is a universal metabolic process that serves to provide a methyl group for biological methylation and the transfer one-carbon units for DNA synthesis (124). DNA methylation relies upon the availability of methyl groups from one-carbon metabolism (125). Therefore, any alterations in folate metabolism will directly contribute to aberrant DNA methylation. Based on the NHANES dataset, the authors' research group previously demonstrated (in 2015) that, despite a lower dietary intake, a high BMI is notably associated with an increased red blood cell folate level and this association is of particular significance for pre-menopausal women (126). In another recent study by the authors, using mammary tissue from pre-menopausal women who underwent reduction mammoplasty, a positive association was confirmed between BMI and breast tissue folate levels, with an increase of $2.65 \mathrm{ng} / \mathrm{g}$ folate per every 5 -unit increase in BMI $(\mathrm{P}<0.01)(41)$. Following this observation, the DNA methylation of $L I N E-1$ was also found to be significantly associated with BMI $(\mathrm{P}<0.05)(41)$. These data indicates a novel mechanism responsible for the inverse association between obesity and pre-BC: Obesity exerts its protective effects against pre-BC by modifying folate metabolism and DNA methylation (Fig. 2).

\section{Conclusions and future perspectives}

Overweight and obesity have reached an epidemic level in the US and worldwide. BC has surpassed lung cancer as the most commonly diagnosed cancer among women in the US and globally. The association between obesity and BC is complex; a well-established positive association exists between obesity and post-BC, whereas an inverse association exists prior to menopause. In the present review, in addition to the overall review of obesity and $\mathrm{BC}$ in public health, the authors provided insight into the following: i) The epigenetic phenomena (particularly the well-studied DNA methylation) in $\mathrm{BC}$; ii) the mediating effects of obesity on DNA methylation; iii) the associations between obesity and DNA methylation (including both gene-specific and global methylation); and more importantly, iv) the mechanism through which folate metabolism/DNA methylation are potentially responsible for the associations between obesity and $\mathrm{BC}$. To date, accumulating evidence has demonstrated associations among obesity, DNA methylation and BC. Previous studies by the authors' group have provided a potential mechanism through which obesity may exert a protective effect on pre-BC by improving folate metabolism and DNA methylation $(41,126)$. However, i) the epigenetic signature profiles through which obesity is linked to $\mathrm{BC}$ remains to be defined; ii) the causality between obesity and epigenetic alterations in terms of breast tumorigenesis remains unclear; and iii) the mechanisms through which obesity exerts paradoxical effects on pre-vs. post-BC via epigenetic mechanisms have not yet been elucidated. The collection of data on DNA methylation profiles and the understanding of the epigenetic contribution to the linkage of obesity and $\mathrm{BC}$ are still in the initial stages. Therefore, a clear and reliable conclusion regarding the effects of obesity on DNA methylation and mammary tumorigenesis can only be speculated. In summary, the literature presented in the present review indicates that epigenetic alterations represent a mediator of the association between obesity and BC. However, a number of questions remain unanswered, as mentioned above. Thus, detailed studies using animal models and the analyses of human tissue biopsies are warranted.

\section{Acknowledgements}

Not applicable.

\section{Funding}

The present study was supported by a grant from the Rays of Hope Center for Breast Cancer Research, Baystate Medical Center (no. 113-1535), and in part by a USDA/Hatch grant (no. MAS00514-1013548).

\section{Availability of data and materials}

Not applicable. 


\section{Authors' contributions}

ZL fully contributed to conceiving the theme, designing the framework, and manuscript writing of the review article. ALMF and RR performed the literature search and selection of the studies cited in the present review, and contributed to the manuscript writing and revision. ALMF, RR and ZL confirm the authenticity of all the raw data.

\section{Ethics approval and consent to participate}

Not applicable.

\section{Patient consent for publication}

Not applicable.

\section{Competing interests}

$\mathrm{ZL}$ is an Editor of the journal, but had no personal involvement in the reviewing process, or any influence in terms of adjudicating on the final decision, for this article. ZL has no other competing interests and the other authors (ALMF and $\mathrm{RR}$ ) also declare that they have no competing interests.

\section{References}

1. Sung H, Ferlay J, Siegel RL, Laversanne M, Soerjomataram I, Jemal A and Bray F: Global cancer statistics 2020: GLOBOCAN estimates of incidence and mortality worldwide for 36 cancers in 185 Countries. CA Cancer J Clin 71: 209-249, 2021.

2. Siegel RL, Miller KD and Jemal A: Cancer statistics, 2020. CA Cancer J Clin 70: 7-30, 2020.

3. Torre LA, Islami F, Siegel RL, Ward EM and Jemal A: Global cancer in women: Burden and trends. Cancer Epidemiol Biomarkers Prev 26: 444-457, 2017

4. Rossouw JE, Anderson GL, Prentice RL, LaCroix AZ, Kooperberg C, Stefanick ML, Jackson RD, Beresford SA, Howard BV, Johnson KC, et al: Risks and benefits of estrogen plus progestin in healthy postmenopausal women: Principal results From the Women's Health Initiative randomized controlled trial. JAMA 288: 321-333, 2002.

5. Breen N, Cronin KA, Tiro JA, Meissner HI, McNeel TS, Sabatino SA, Tangka FK and Taplin SH: Was the drop in mammography rates in 2005 associated with the drop in hormone therapy use? Cancer 117: 5450-5460, 2011.

6. Breen N, Gentleman JF and Schiller JS: Update on mammography trends: Comparisons of rates in 2000, 2005, and 2008 Cancer 117: 2209-2218, 2011.

7. DeSantis CE, Ma J, Gaudet MM, Newman LA, Miller KD, Goding Sauer A, Jemal A and Siegel RL: Breast cancer statistics, 2019. CA Cancer J Clin 69: 438-4351, 2019.

8. Pfeiffer RM, Webb-Vargas Y, Wheeler W and Gail MH: Proportion of U.S. Trends in breast cancer incidence attributable to long-term changes in risk factor distributions. Cancer Epidemiol Biomarkers Prev 27: 1214-1222, 2018.

9. World Health Organization (WHO): Obesity and Overweight. WHO, Geneva, 2021. https://www.who. int/news-room/fact-sheets/detail/obesity-and-overweight. Accessed June 9, 2021.

10. Hales CM, Carroll MD, Fryar CD and Ogden CL: Prevalence of obesity and severe obesity among adults: United States, 2017-2018. NCHS Data Brief 360: 1-8, 2020.

11. Centers for Disease Control and Prevention (CDC): Overweight \& Obesity. CDC, Atlanta, GA, 2021. https://www.cdc. gov/obesity/data/adult.html. Last reviewed June 7, 2021.

12. Calle EE and Kaaks R: Overweight, obesity and cancer: Epidemiological evidence and proposed mechanisms. Nat Rev Cancer 4: 579-591, 2004.
13. Finkelstein EA, Khavjou OA, Thompson H, Trogdon JG, Pan L, Sherry B and Dietz W: Obesity and severe obesity forecasts through 2030. Am J Prev Med 42: 563-570, 2012.

14. National Heart, Lung, and Blood Institute (NIH): Managing overweight and obesity in adults: Systematic evidence review from the Obesity Expert Panel. NIH, Bethesda, MD, 2013.

15. Field AE, Coakley EH, Must A, Spadano JL, Laird N, Dietz WH, Rimm E and Colditz GA: Impact of overweight on the risk of developing common chronic diseases during a 10 -year period. Arch Intern Med 161: 1581-1586, 2001.

16. Sturm R and An R: Obesity and economic environments. CA Cancer J Clin 64: 337-350, 2014.

17. Colditz GA, Willett WC, Stampfer MJ, Manson JE, Hennekens CH, Arky RA and Speizer FE: Weight as a risk factor for clinical diabetes in women. Am J Epidemiol 132: 501-513, 1990.

18. Brown JC, Carson TL, Thompson HJ and Agurs-Collins T: The triple health threat of diabetes, obesity, and cancer-epidemiology, disparities, mechanisms, and interventions. Obesity (Silver Spring) 29: 954-959, 2021.

19. Scully T, Ettela A, LeRoith D and Gallagher EJ: Obesity, type 2 diabetes, and cancer risk. Front Oncol 10: 615375, 2021.

20. Rahman I, Athar MT and Islam M: Type 2 diabetes, obesity, and cancer share some common and critical pathways. Front Oncol 10: 600824, 2021

21. Fung TT, Rimm EB, Spiegelman D, Rifai N, Tofler GH, Willett WC and Hu FB: Association between dietary patterns and plasma biomarkers of obesity and cardiovascular disease risk. Am J Clin Nutr 73: 61-67, 2001.

22. Wilding JPH and Jacob S: Cardiovascular outcome trials in obesity: A review. Obes Rev 22: e13112, 2021.

23. Swanson SM, Harper J and Zisman TL: Obesity and inflammatory bowel disease: Diagnostic and therapeutic implications. Curr Opin Gastroenterol 34: 112-119, 2018.

24. Dai ZH, Xu XT and Ran ZH: Associations between obesity and the effectiveness of anti-tumor necrosis factor- $\alpha$ agents in inflammatory bowel disease patients: A literature review and meta-analysis. Ann Pharmacother 54: 729-741, 2020.

25. Horesh A, Tsur AM, Bardugo A and Twig G: Adolescent and childhood obesity and excess morbidity and mortality in young adulthood-a systematic review. Curr Obes Rep: May 5, 2021 (Epub ahead of print).

26. Yates T, Razieh C, Zaccardi F, Rowlands AV, Seidu S, Davies MJ and Khunti K: Obesity, walking pace and risk of severe COVID-19 and mortality: Analysis of UK Biobank. Int J Obes (Lond) 45: 1155-1159, 2021.

27. Masters RK, Reither EN, Powers DA, Yang YC, Burger AE and Link BG: The impact of obesity on US mortality levels: The importance of age and cohort factors in population estimates. Am J Public Health 103: 1895-1901, 2013.

28. Brown KA: Metabolic pathways in obesity-related breast cancer. Nat Rev Endocrinol 17: 350-363, 2021.

29. Centers for Disease Control and Prevention (CDC): Cancers Associated with Overweight and Obesity Make up 40 percent of Cancers Diagnosed in the United States. CDC, Atlanta, GA, 2017. Accessed October 3, 2017.

30. World Cancer Research Fund (WCRF): Continuous Update Project Report: Diet, Nutrition, Physical Activity and Breast Cancer. WCRF, London, 2017. https://www.wcrf. org/sites/default/files/Breast-Cancer-2017-Report.pdf. Accessed July 20, 2020.

31. Calle EE, Rodriguez C, Walker-Thurmond $\mathrm{K}$ and Thun MJ: Overweight, obesity, and mortality from cancer in a prospectively studied cohort of U.S. adults. N Engl J Med 348: 1625-1638, 2003.

32. Tamimi RM, Spiegelman D, Smith-Warner SA, Wang M, Pazaris M, Willett WC, Eliassen AH and Hunter DJ: Population attributable risk of modifiable and nonmodifiable breast cancer risk factors in postmenopausal breast cancer. Am J Epidemiol 184: 884-893, 2016.

33. Silvera SA, Jain M, Howe GR, Miller AB and Rohan TE: Energy balance and breast cancer risk: A prospective cohort study. Breast Cancer Res Treat 97: 97-106, 2006.

34. Anderson GL and Neuhouser ML: Obesity and the risk for premenopausal and postmenopausal breast cancer. Cancer Prev Res (Phila) 5: 515-521, 2012.

35. Nelson HD, Zakher B, Cantor A, Fu R, Griffin J, O'Meara ES, Buist DS, Kerlikowske K, van Ravesteyn NT, Trentham-Dietz A, et al: Risk factors for breast cancer for women aged 40 to 49 years: A systematic review and meta-analysis. Ann Intern Med 156: 635-648, 2012. 
36. Munsell MF, Sprague BL, Berry DA, Chisholm G and Trentham-Dietz A: Body mass index and breast cancer risk according to postmenopausal estrogen-progestin use and hormone receptor status. Epidemiol Rev 36: 114-1136, 2014.

37. Renehan AG, Tyson M, Egger M, Heller RF and Zwahlen M: Body-mass index and incidence of cancer: A systematic review and meta-analysis of prospective observational studies. Lancet 371: 569-578, 2008

38. Ursin G, Longnecker MP, Haile RW and Greenland S: A meta-analysis of body mass index and risk of premenopausal breast cancer. Epidemiology 6: 137-1341, 1995.

39. van den Brandt PA, Spiegelman D, Yaun SS, Adami HO, Beeson L, Folsom AR, Fraser G, Goldbohm RA, Graham S, Kushi L, et al: Pooled analysis of prospective cohort studies on height, weight, and breast cancer risk. Am J Epidemiol 152: 514-527, 2000

40. De Pergola G and Silvestris F: Obesity as a major risk factor for cancer. J Obes 2013: 291546, 2013.

41. Frederick AM, Guo C, Meyer A, Yan L, Schneider SS and Liu Z: The influence of obesity on folate status, DNA methylation and cancer-related gene expression in normal breast tissues from premenopausal women. Epigenetics 16: 458-467, 2021.

42. NIH Roadmap Epigenomics Project. Overview. http://www. roadmapepigenomics.org/overview. Access June 1, 2021.

43. Lo PK and Sukumar S: Epigenomics and breast cancer. Pharmacogenomics 9: 1879-1902, 2008.

44. Huang Y, Nayak S, Jankowitz R, Davidson NE and Oesterreich S: Epigenetics in breast cancer: What's new? Breast Cancer Res 13: $225,2011$.

45. Kasiappan R and Rajarajan D: Role of MicroRNA regulation in obesity-associated breast cancer: Nutritional perspectives. Adv Nutr 8: 868-888, 2017

46. Gyorffy B, Bottai G, Fleischer T, Munkácsy G, Budczies J, Paladini L, Børresen-Dale AL, Kristensen VN and Santarpia L: Aberrant DNA methylation impacts gene expression and prognosis in breast cancer subtypes. Int J Cancer 138: 87-97, 2016.

47. Mahdavi M, Nassiri M, Kooshyar MM, Vakili-Azghandi M Avan A, Sandry R, Pillai S, Lam AK and Gopalan V: Hereditary breast cancer; Genetic penetrance and current status with BRCA J Cell Physiol 234: 5741-5750, 2019.

48. Luque M, Arranz F, Cueva JF, de Juan A, García-Teijido P, Calvo L, Peláez I, García-Palomo A, García-Mata J, Antolín S, et al: Breast cancer management in the elderly. Clin Transl Oncol 16: 351-361, 2014.

49. Daly AA, Rolph R, Cutress RI and Copson ER: A review of modifiable risk factors in young women for the prevention of breast cancer. Breast Cancer (Dove Med Press) 13: 241-257, 2021

50. Sjoblom T, Jones S, Wood LD, Parsons DW, Lin J, Barber TD, Mandelker D, Leary RJ, Ptak J, Silliman N, et al: The consensus coding sequences of human breast and colorectal cancers. Science 314: 268-274, 2006.

51. Esteller M: Cancer epigenomics: DNA methylomes and histone-modification maps. Nat Rev Genet 8: 286-298, 2007.

52. Esteller M: Epigenetics in cancer. N Engl J Med 358: 1148-1159, 2008.

53. Wood LD, Parsons DW, Jones S, Lin J, Sjöblom T, Leary RJ, Shen D, Boca SM, Barber T, Ptak J, et al: The genomic landscapes of human breast and colorectal cancers. Science 318 : 1108-1113, 2007.

54. Holliday R: A new theory of carcinogenesis. Br J Cancer 40 513-522, 1979

55. Laird PW: The power and the promise of DNA methylation markers. Nat Rev Cancer 3: 253-266, 2003.

56. Tang Q, Cheng J, Cao X, Surowy H and Burwinkel B: Blood-based DNA methylation as biomarker for breast cancer: A systematic review. Clin Epigenetics 8: 115, 2016.

57. Meeks KAC, Henneman P, Venema A, Burr T, Galbete C, Danquah I, Schulze MB, Mockenhaupt FP, Owusu-Dabo E, Rotimi CN, et al: An epigenome-wide association study in whole blood of measures of adiposity among Ghanaians: The RODAM study. Clin Epigenetics 9: 103, 2017.

58. Crujeiras AB, Diaz-Lagares A, Stefansson OA, Macias-Gonzalez M, Sandoval J, Cueva J, Lopez-Lopez R, Moran S, Jonasson JG, Tryggvadottir L, et al: Obesity and menopause modify the epigenomic profile of breast cancer. Endocr Relat Cancer 24: 351-363, 2017.

59. Szyf M, Pakneshan $P$ and Rabbani SA: DNA methylation and breast cancer. Biochem Pharmacol 68: 1187-1197, 2004

60. Gaudet F, Hodgson JG, Eden A, Jackson-Grusby L, Dausman J, Gray JW, Leonhardt H and Jaenisch R: Induction of tumors in mice by genomic hypomethylation. Science 300: 489-492, 2003
61. Van Tongelen A, Loriot A and De Smet C: Oncogenic roles of DNA hypomethylation through the activation of cancer-germline genes. Cancer Lett 396: 130-137, 2017.

62. Hon GC, Hawkins RD, Caballero OL, Lo C, Lister R, Pelizzola M, Valsesia A, Ye Z, Kuan S, Edsall LE, et al: Global DNA hypomethylation coupled to repressive chromatin domain formation and gene silencing in breast cancer. Genome Res 22: 246-258, 2012.

63. Kuchiba A, Iwasaki M, Ono H, Kasuga Y, Yokoyama S, Onuma H, Nishimura H, Kusama R, Tsugane S and Yoshida T: Global methylation levels in peripheral blood leukocyte DNA by LUMA and breast cancer: A case-control study in Japanese women. Br J Cancer 110: 2765-2771, 2014.

64. Ennour-Idrissi K, Dragic D, Durocher F and Diorio C: Epigenome-wide DNA methylation and risk of breast cancer: A systematic review. BMC Cancer 20: 1048, 2020.

65. Huang TH, Perry MR and Laux DE: Methylation profiling of $\mathrm{CpG}$ islands in human breast cancer cells. Hum Mol Genet 8: 459-470, 1999.

66. Jovanovic J, Ronneberg JA, Tost J and Kristensen V: The epigenetics of breast cancer. Mol Oncol 4: 242-254, 2010.

67. Ordway JM, Budiman MA, Korshunova Y, Maloney RK, Bedell JA, Citek RW, Bacher B, Peterson S, Rohlfing T, Hall J, et al: Identification of novel high-frequency DNA methylation changes in breast cancer. PLoS One 2: e1314, 2007.

68. Mukherjee N, Bhattacharya N, Alam N, Roy A, Roychoudhury S and Panda CK: Subtype-specific alterations of the Wnt signaling pathway in breast cancer: clinical and prognostic significance. Cancer Sci 103: 210-220, 2012.

69. Li Z, Guo X, Wu Y, Li S, Yan J, Peng L, Xiao Z, Wang S, Deng Z, Dai L, et al: Methylation profiling of 48 candidate genes in tumor and matched normal tissues from breast cancer patients. Breast Cancer Res Treat 149: 767-779, 2015.

70. O'Donovan PJ and Livingston DM: BRCA1 and BRCA2: Breast/ovarian cancer susceptibility gene products and participants in DNA double-strand break repair. Carcinogenesis 31: 961-967, 2010.

71. Zhang L and Long X: Association of BRCA1 promoter methylation with sporadic breast cancers: Evidence from 40 studies. Sci Rep 5: 17869, 2015.

72. Hedenfalk I, Duggan D, Chen Y, Radmacher M, Bittner M, Simon R, Meltzer P, Gusterson B, Esteller M, Kallioniemi OP, et al: Gene-expression profiles in hereditary breast cancer. N Engl J Med 344: 539-548, 2001.

73. Duffy MJ, Napieralski R, Martens JW, Span PN, Spyratos F Sweep FC, Brunner N, Foekens JA and Schmitt M; EORTC PathoBiology Group: Methylated genes as new cancer biomarkers. Eur J Cancer 45: 335-346, 2009.

74. Brooks J, Cairns P and Zeleniuch-Jacquotte A: Promoter methylation and the detection of breast cancer. Cancer Causes Control 20: 1539-1550, 2009.

75. García-Giménez JL, Sanchis-Gomar F, Lippi G, Mena S, Ivars D, Gomez-Cabrera MC, Viña J and Pallardó FV: Epigenetic biomarkers: A new perspective in laboratory diagnostics. Clin Chim Acta 413: 1576-1582, 2012.

76. Parashar S, Cheishvili D, Mahmood N, Arakelian A, Tanvir I, Khan HA, Kremer R, Mihalcioiu C, Szyf M and Rabbani SA: DNA methylation signatures of breast cancer in peripheral T-cells. BMC Cancer 18: 574, 2018.

77. Szyf M: DNA methylation signatures for breast cancer classification and prognosis. Genome Med 4: 26, 2012

78. Li Y, Melnikov AA, Levenson V, Guerra E, Simeone P, Alberti S and Deng Y: A seven-gene CpG-island methylation panel predicts breast cancer progression. BMC Cancer 15: 417, 2015.

79. Stirzaker C, Zotenko E, Song JZ, Qu W, Nair SS, Locke WJ, Stone A, Armstong NJ, Robinson MD, Dobrovic A, et al: Methylome sequencing in triple-negative breast cancer reveals distinct methylation clusters with prognostic value. Nat Commun 6: 5899, 2015.

80. Samblas M, Milagro FI and Martinez A: DNA methylation markers in obesity, metabolic syndrome, and weight loss. Epigenetics 14: 421-444, 2019.

81. Ouni M and Schurmann A: Epigenetic contribution to obesity. Mamm Genome 31: 134-145, 2020.

82. Donovan MG, Wren SN, Cenker M, Selmin OI and Romagnolo DF: Dietary fat and obesity as modulators of breast cancer risk: Focus on DNA methylation. Br J Pharmacol 177: 1331-1350, 2020

83. Perfilyev A, Dahlman I, Gillberg L, Rosqvist F, Iggman D, Volkov P, Nilsson E, Risérus U and Ling C: Impact of polyunsaturated and saturated fat overfeeding on the DNA-methylation pattern in human adipose tissue: A randomized controlled trial. Am J Clin Nutr 105: 991-1000, 2017. 
84. Jacobsen SC, Brøns C, Bork-Jensen J, Ribel-Madsen R, Yang B, Lara E, Hall E, Calvanese V, Nilsson E, Jørgensen SW, et al: Effects of short-term high-fat overfeeding on genome-wide DNA methylation in the skeletal muscle of healthy young men. Diabetologia 55: 3341-3349, 2012.

85. Milagro FI, Campion J, Cordero P, Goyenechea E, Gómez-Uriz AM, Abete I, Zulet MA and Martínez JA: A dual epigenomic approach for the search of obesity biomarkers: DNA methylation in relation to diet-induced weight loss. FASEB J 25 : 1378-1389, 2011.

86. Bouchard L, Rabasa-Lhoret R, Faraj M, Lavoie ME, Mill J, Pérusse L and Vohl MC: Differential epigenomic and transcriptomic responses in subcutaneous adipose tissue between low and high responders to caloric restriction. Am J Clin Nutr 91: 309-320, 2010.

87. Voisin S, Eynon N, Yan X and Bishop DJ: Exercise training and DNA methylation in humans. Acta Physiol (Oxf) 213: 39-59, 2015.

88. Barres R, Yan J, Egan B, Treebak JT, Rasmussen M, Fritz T, Caidahl K, Krook A, O'Gorman DJ and Zierath JR: Acute exercise remodels promoter methylation in human skeletal muscle. Cell Metab 15: 405-411, 2012.

89. Kanzleiter T, Jahnert M, Schulze G, Selbig J, Hallahan N, Schwenk RW and Schürmann A: Exercise training alters DNA methylation patterns in genes related to muscle growth and differentiation in mice. Am J Physiol Endocrinol Metab 308 : E912-E920, 2015.

90. Sailani MR, Halling JF, Møller HD, Lee H, Plomgaard P, Pilegaard H, Snyder MP and Regenberg B: Lifelong physical activity is associated with promoter hypomethylation of genes involved in metabolism, myogenesis, contractile properties and oxidative stress resistance in aged human skeletal muscle. Sci Rep 9: 3272, 2019.

91. Maugeri A: The effects of dietary interventions on DNA methylation: Implications for obesity management. Int J Mol Sci 21 8670,2020

92.Ling C and Ronn T: Epigenetics in Human Obesity and type 2 diabetes. Cell Metab 29: 1028-1044, 2019.

93. Bombonati A and Sgroi DC: The molecular pathology of breast cancer progression. J Pathol 223: 307-317, 2011.

94. Robertson KD: DNA methylation, methyltransferases, and cancer. Oncogene 20: 3139-3155, 2001.

95. Fleischer T, Tekpli X, Mathelier A, Wang S, Nebdal D, Dhakal HP, Sahlberg KK and Schlichting E; Oslo Breast Cancer Research Consortium (OSBREAC), Børresen-Dale AL, et al: DNA methylation at enhancers identifies distinct breast cancer lineages. Nat Commun 8: 1379, 2017.

96. Jin W, Li QZ, Zuo YC, Cao YN, Zhang LQ, Hou R and Su WX: Relationship Between DNA methylation in key region and the differential expressions of genes in human breast tumor tissue. DNA Cell Biol 38: 49-62, 2019.

97. Hair BY, Xu Z, Kirk EL, Harlid S, Sandhu R, Robinson WR, Wu MC, Olshan AF, Conway K, Taylor JA and Troester MA: Body mass index associated with genome-wide methylation in breast tissue. Breast Cancer Res Treat 151: 453-463, 2015.

98. Hair BY, Troester MA, Edmiston SN, Parrish EA, Robinson WR, Wu MC, Olshan AF, Swift-Scanlan T and Conway K: Body mass index is associated with gene methylation in estrogen receptor-positive breast tumors. Cancer Epidemiol Biomarkers Prev 24: 580-586, 2015.

99. Dragic D, Ennour-Idrissi K, Michaud A, Chang SL, Durocher F and Diorio C: Association Between BMI and DNA methylation in blood or normal adult breast tissue: A systematic review. Anticancer Res 40: 1797-1808, 2020.

100. Bosviel R, Garcia S, Lavediaux G, Michard E, Dravers M, Kwiatkowski F, Bignon YJ and Bernard-Gallon DJ: BRCA1 promoter methylation in peripheral blood DNA was identified in sporadic breast cancer and controls. Cancer Epidemiol 36 e177-e182, 2012.

101. Sturgeon SR, Balasubramanian R, Schairer C, Muss HB, Ziegler RG and Arcaro KF: Detection of promoter methylation of tumor suppressor genes in serum DNA of breast cancer cases and benign breast disease controls. Epigenetics 7: 1258-1267, 2012.

102. Hasan TN, Leena Grace B, Shafi G and Syed R: Association of BRCA1 promoter methylation with rs 11655505 (c.2265C $>\mathrm{T}$ ) variants and decreased gene expression in sporadic breast cancer. Clin Transl Oncol 15: 555-562, 2013.

103. Buyru N, Altinisik J, Ozdemir F, Demokan S and Dalay N: Methylation profiles in breast cancer. Cancer Invest 27: 307-312, 2009.
104. Iwamoto T, Yamamoto N, Taguchi T, Tamaki Y and Noguchi S: BRCA1 promoter methylation in peripheral blood cells is associated with increased risk of breast cancer with BRCA1 promoter methylation. Breast Cancer Res Treat 129: 69-77, 2011.

105. Dobrovic A and Simpfendorfer D: Methylation of the BRCA1 gene in sporadic breast cancer. Cancer Res 57: 3347-3350, 1997.

106. Gupta S, Jaworska-Bieniek K, Narod SA, Lubinski J, Wojdacz TK and Jakubowska A: Methylation of the BRCA1 promoter in peripheral blood DNA is associated with triple-negative and medullary breast cancer. Breast Cancer Res Treat 148: 615-622, 2014.

107. Peplonska B, Bukowska A, Wieczorek E, Przybek M, Zienolddiny S and Reszka E: Rotating night work, lifestyle factors, obesity and promoter methylation in BRCA1 and BRCA2 genes among nurses and midwives. PLoS One 12 e0178792, 2017.

108. McCullough LE, Chen J, Cho YH, Khankari NK, Bradshaw PT, White AJ, Garbowski G, Teitelbaum SL, Terry MB, Neugut AI, et al: DNA methylation modifies the association between obesity and survival after breast cancer diagnosis. Breast Cancer Res Treat 156: 183-194, 2016.

109. Choi JY, James SR, Link PA, McCann SE, Hong CC, Davis W, Nesline MK, Ambrosone CB and Karpf AR: Association between global DNA hypomethylation in leukocytes and risk of breast cancer. Carcinogenesis 30: 1889-1897, 2009.

110. Cho YH, Yazici H, Wu HC, Terry MB, Gonzalez K, Qu M, Dalay N and Santella RM: Aberrant promoter hypermethylation and genomic hypomethylation in tumor, adjacent normal tissues and blood from breast cancer patients. Anticancer Res 30 2489-2496, 2010.

111. Xu X, Gammon MD, Hernandez-Vargas H,Herceg Z, Wetmur JG, Teitelbaum SL, Bradshaw PT, Neugut AI, Santella RM and Chen J: DNA methylation in peripheral blood measured by LUMA is associated with breast cancer in a population-based study. FASEB J 26: 2657-2666, 2012

112. Friso S, Choi SW, Dolnikowski GG and Selhub J: A method to assess genomic DNA methylation using high-performance liquid chromatography/electrospray ionization mass spectrometry. Anal Chem 74: 4526-4531, 2002

113. Beck CR, Garcia-Perez JL, Badge RM and Moran JV: LINE-1 elements in structural variation and disease. Annu Rev Genomics Hum Genet 12: 187-215, 2011.

114. Carraro JC, Mansego ML, Milagro FI, Chaves LO, Vidigal FC, Bressan J and Martínez JA: LINE-1 and inflammatory gene methylation levels are early biomarkers of metabolic changes: Association with adiposity. Biomarkers 21: 625-632, 2016.

115. Karimi M, Johansson S and Ekstrom TJ: Using LUMA: A Luminometric-based assay for global DNA-methylation. Epigenetics 1: 45-48, 2006

116. Karimi M, Johansson S, Stach D, Corcoran M, Grandér D Schalling M, Bakalkin G, Lyko F, Larsson C and Ekström TJ: LUMA (LUminometric Methylation Assay)-a high throughput method to the analysis of genomic DNA methylation. Exp Cell Res 312: 1989-1995, 2006

117. Kurdyukov S and Bullock M: DNA methylation analysis: Choosing the right method. Biology (Basel) 5: 3, 2016.

118. Marques-Rocha JL, Milagro FI, Mansego ML, Mourao DM, Martinez JA and Bressan J: LINE-1 methylation is positively associated with healthier lifestyle but inversely related to body fat mass in healthy young individuals. Epigenetics 11: 49-60, 2016.

119. Feinberg AP, Irizarry RA, Fradin D, Aryee MJ, Murakami $P$, Aspelund T, Eiriksdottir G, Harris TB, Launer L, Gudnason V and Fallin MD: Personalized epigenomic signatures that are stable over time and covary with body mass index. Sci Transl Med 2: 49ra67, 2010

120. Piyathilake C, Badiga S, Johanning G, Alvarez R and Partridge E: Predictors and health consequences of epigenetic changes associated with excess body weight in women of child-bearing age. In: Proceedings of the 35th Annual Meeting of the American Society of Preventive Oncology. ASPO, Las Vegas, NV, 2011.

121. Zhu ZZ, Hou L, Bollati V, Tarantini L, Marinelli B, Cantone L, Yang AS, Vokonas P, Lissowska J, Fustinoni S, et al: Predictors of global methylation levels in blood DNA of healthy subjects: A combined analysis. Int J Epidemiol 41: 126-139, 2012.

122. Boyne DJ, Friedenreich CM, McIntyre JB, Courneya KS and King WD: Associations between adiposity and repetitive element DNA methylation in healthy postmenopausal women. Epigenomics 9: 1267-1277, 2017 
123. Xu Z, Sandler DP and Taylor JA: Blood DNA methylation and breast cancer: A prospective case-cohort analysis in the sister study. J Natl Cancer Inst 112: 87-94, 2020.

124. Ducker GS and Rabinowitz JD: One-carbon metabolism in health and disease. Cell Metab 25: 27-42, 2017.

125. Murin R, Vidomanova E, Kowtharapu BS, Hatok J and Dobrota D: Role of S-adenosylmethionine cycle in carcinogenesis. Gen Physiol Biophys 36: 513-520, 2017.
126. Bird JK, Ronnenberg AG, Choi SW, Du F, Mason JB and Liu Z: Obesity is associated with increased red blood cell folate despite lower dietary intakes and serum concentrations. J Nutr 145: 79-86, 2015.

(i) (-) $\Theta$ This work is licensed under a Creative Commons cc) Atribution-NonCommercial-NoDerivatives 4.0 International (CC BY-NC-ND 4.0) License. 